\title{
TRUMP AND THE RESURGENCE OF AMERICAN NOIR
}

\author{
VIRGINIA NEWHALL RADEMACHER
}

\begin{abstract}
This essay examines the political persona of Donald Trump as mediated by the imagery of hardboiled detective fiction and film noir. By evoking and distorting noir's challenge to the status quo, its suspicion of systems of power and questioning of dominant norms, Trump has fashioned his political persona in ways that deliberately revise the popular conception of the hardboiled hero as brash-talking rebel at the margins of a corrupt system. Reading Trump's persona through the mediating function of noir exposes how Trump's rhetoric plays on, and benefits from, a theme of citizen estrangement while simultaneously reinforcing political expediency and self-interested power. Moreover, it is not only Trump who uses noir imagery provocatively to shape his political image. The media have also participated in crafting images of Trump as either entertaining disruptor or more darkly destabilising. As responses to crises of capitalism, corruption, and social fracture, noir narratives provide critical ways of investigating periods of disequilibrium and their resurfacing in the present. Analysing the production, expression, and reception of Trump's political persona through the historical and discursive structures of noir underscores the salience of the study of persona to reveal underlying fissures in current American politics and society.
\end{abstract}

\section{KEY WORDS}

Noir; Persona; U.S. Politics; Donald Trump; Mediated Identity; Hardboiled Detective Fiction

This essay considers the political persona of Donald Trump as mediated by the imagery of hardboiled detective fiction and film noir. As responses to crises of capitalism, corruption, and social fracture, noir narratives provide critical ways of investigating periods of disequilibrium and their resurfacing in the present. Trump's campaign for the U.S. presidency has confounded the traditional power bases of the political establishment and disrupted norms of political discourse. The decision to analyse Trump through a noir lens also emerges from the differing ways in which both Trump and mainstream media have depicted this disruption of political norms in terms we might readily associate with noir. While the media have alternately presented Trump as entertaining provocateur or more dangerously destabilising, Trump has cast his political persona as defiant outsider, exposing a dark vision of American vulnerability.

Analysing the production, expression, and reception of Trump's political persona through the historical and discursive structures of noir underscores the salience of the study of persona to reveal underlying fissures in current American politics and society. Drawing from John Cawelti's analysis of the transformation of noir as a mode of interrogating the cultural myths that it embodies, I analyse the persona of Trump as fake hardboiled hero and examine how Trump's rhetoric plays on, and benefits from, themes of citizen estrangement while 
simultaneously reinforcing elite networks of power. Both Trump and the media use noir imagery provocatively to shape his political image. I examine to what extent these representations of his political persona sensationalise Trump or turn him into a caricature that avoids deeper questioning, and how noir's psychological framework may help to explain the appeal of Trump's political persona among his supporters.

As a narrative and analytical mode of social criticism, noir provides a medium for investigating darker views of reality and human nature through character study and sociological investigation. Through what he refers to as noir's "transformational grammar," a "term rhetoricians use to refer to the ability to intuit the meanings below the visible surface," Christopher Wilson argues that "[n]oir allows its writers to interrelate deep structures of a political landscape-often to sort out its audible or silent voices-or to sense a hidden social syntax beneath public discourse" (489). Applying this conceptual framework, my analysis involves not just the role of noir as narrative vehicle, or its relevance as social critique, but also its function as mode of inquiry into the construction of Trump's political persona and its discursive layers.

\section{TRUMP's PERSONA AS HARDBOILED ANTI-HERO}

Through noir's dual functions to expose and critique social realities, I examine how Trump's political persona draws from and deforms the archetypal image of the hardboiled protagonist, and how demythologising this revision of the genre's code and symbolism serves as potent social analysis. Wilson observes that "[n]oir is perhaps best understood as a mode of examining the connections between outer, elite networks of power that struggle for dominance and the interiorized (and phantasmal) states of citizen estrangement that come to life within that struggle" (488). Originating in the pulp magazines, formalised in interwar literature, and then further popularised in noir films of the 1940s and 50s, the hardboiled protagonist has continued to find resonance in contemporary American cultural production. As conceived by Raymond Chandler or Dashiell Hammett, the hardboiled hero is a tough-talking outsider who operates at the margins of law and civility as he navigates a corrupt society. Frequently a private investigator with "no qualms about violence and questionable attitudes toward women," he is willing to break the rules and to use violence if necessary in order serve his own code of justice (Cober-Lake). On at least a surface level, Trump appears to reference and play upon established conventions of the hardboiled tradition in crafting his political narrative as selfreliant outlaw hero: Here comes the guy who is all rage against reason, action rather than armchair deliberateness, a brash-talking, shoot from the hip truth-teller who is not afraid to go where others won't.

In their introduction to the first edition of Persona Studies, P. David Marshall and Kim Barbour observe the "enormous activity and energy in the production, construction, and exhibition of personas" that has "led to this intensive focus on constructing strategic masks of identity" (1). Donald Trump is an example of someone who is profoundly aware of his own role in creating and "performing" this strategic public self. In his cover article in The Atlantic, "The Mind of Donald Trump," Dan McAdams observes how "Trump seems supremely cognizant of the fact that he is always acting. He moves through life like a man who knows he is always being observed."

Trump's adoption of the hardboiled persona reflects various performative strategies. John Corner has argued that political personhood is mediated in three primary ways: iconically (displaying the "demeanour, posture and associative contexts of the political self"), vocally ("such that the significance of what is said becomes more interfused with how it is said and the 
political and the personal are thus more closely articulated") and kinetically (the "political self in action and interaction") (388). Notably, Trump uses all three approaches-iconic, vocal, and kinetic - to fuel his noir narrative and present himself as hardboiled protagonist. Within this self-fashioned narrative, he confronts a failed and corrupt political system, comes into conflict with representatives of the official machinery, uses street-smart vernacular to shoot straight with those who feel disenfranchised from the political establishment, and is a man of actionconstantly moving and doing-rather than contemplating.

Trump is not only absorbed with his public image or celebrity, but with shaping his political personality through confrontations that capitalise on perceived weaknesses in ways that he believes bolster his own comparative strength and status. "I never had a failure," Trump said in one interview, despite his repeated corporate bankruptcies and business setbacks, "because I always turned a failure into a success" (Barbaro, "What Drives Donald Trump?"). For example, as part of the cover and in the content of his 2015 book Crippled America: How to Make America Great Again, Trump comments on the process of carefully curating the persona to be profiled on the cover of this book: "Some readers may be wondering why the picture we used on the cover of this book is so angry and mean looking. [...] In this book we're talking about Crippled America. Unfortunately, there's very little that's nice about it. So, I wanted a picture that reflected the anger and unhappiness that I feel, rather than joy" (ix). ${ }^{i}$

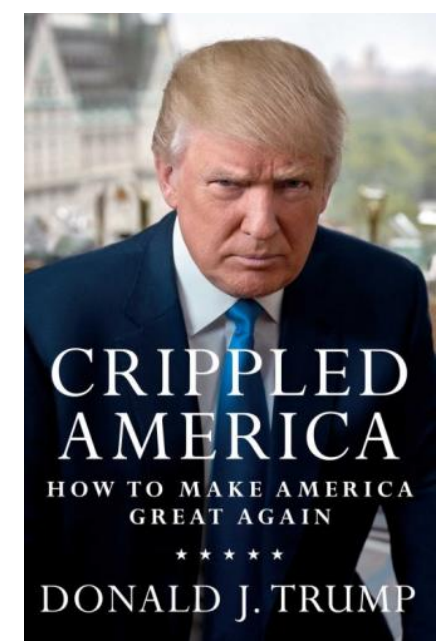

Figure 1: Cover image for Crippled America

Noting that "people say that I have self-confidence," Trump contends that he has just been carefully building a case to defend himself against myriad potential critics; including the "relentless and incompetent naysayers of the left," politicians who are really "losers," lobbyists "lining their pockets," "biased media," "illegal immigrants" who have "taken jobs that should go to people here legally," lawyers and judges who "recklessly appointed themselves," and a Presidency and Executive Branch marred by "incompetency beyond belief." In response to their criticism of ideas such as building a huge wall along the Mexican border, Trump contends, "I have proven everybody wrong. EVERYBODY! [...] I'm not playing by the usual status-quo rules [...] I am telling it like it is" (Crippled America 9).

Reading Trump's persona through the mediating function of noir exposes and demythologises "the hidden social syntax" within the discursive model. To examine Trump's political persona through the mediating function of noir as narrative and analytical mode also demonstrates intersections with broader cultural and political discourses around gender, race, and citizenship. As Justin Cober-Lake observes in his review of Christopher Breu's Hard-Boiled Masculinities, "these [hardboiled] men aren't simply literary archetypes, they both influence and 
represent conceptions of masculinity that play out in the real world." In a similar fashion, Trump's performance with these rhetorical strategies, as constitutive of his political persona, has public and political significance beyond questions of self-representation.

Through differing modes of "generic transformation," John Cawelti considers how appropriating the conventional genre elements of noir and applying them in an altered context allows us to perceive these traditional forms and images in a new way (504). He identifies the hardboiled tradition - "a pattern of narrative known throughout the culture and presented in many different versions by many different tellers" - as an important part of the popular mythology of American identity (499). Yet, as Cawelti suggests, the significance of testing, challenging, and even subverting the traditional conventions of genre coincides importantly with times of cultural transition. Using the 1974 film Chinatown as an example (this period referencing another time of deep distrust and upheaval in American politics), Cawelti notes that despite how "close a resemblance" Chinatown bears to the hardboiled formula, the film "deviates increasingly from the myth until, by the end of the story, the film arrives at an ending almost contrary to that of the myth" (501, emphasis added). It is my contention that we could say this similarly of Trump's adoption of the hardboiled archetype and the noir narrative he has used to justify his political persona; despite resemblance to the myth, "there is something not quite right, something disturbingly off about it" (499). While Trump constructs his political persona in ways that play to the image of the hardboiled protagonist, the underlying syntax simultaneously undercuts key facets of this symbolism, challenging Trump's control over its communication and signification.

By evoking and distorting noir's challenge to the status quo, its suspicion of systems of power and questioning of dominant norms, Trump maintains that he is simply exposing truths no other politician has the guts to acknowledge. In fashioning this political persona, Trump deliberately revises the popular conception of the hardboiled hero as brash-talking rebel at the margins of a corrupt society, instead using nostalgia over "lost greatness" to justify violence and to assert political expediency as a means of self-interested power. Employing Cawelti's modes of generic transformation, I consider how Trump's surface play and performance of his hardboiled political persona undermine conventional symbolism and meaning to reinforce a political construction "almost contrary to that of the myth" (Cawelti 501). In this way, noir mediates the construction of Trump's political persona in ways that challenge and destabilise his dominant self-narrative. If we think of noir as both a style and as a mode of seeing the world with suspicion that something hidden, often something darker, lies beneath the surface, then we can see how Trump's noir styling of his persona coupled with a noir methodology invites us to interrogate the construction of this persona and to expose veiled meanings.

In what ways is Trump's political persona a "narrative of falseness and fiction" and how does the rhetoric of noir mediate this construction? I want to concentrate on three particular aspects of his self-fashioned "strategic public identity" (Marshall and Barbour 4): 1) hardboiled toughness; 2) the use of nostalgia; 3 ) the American success myth and biggest "losers." Cawelti observes how one way that a genre's conventional meaning is demythologised and shown to embody an "inadequate and destructive" myth is by deliberately invoking the basic characteristics of a traditional genre, but in ways that subvert its original meaning (507). As I have suggested, Trump's tough guise plays on the established conventions of the hardboiled archetype. Psychologist Dan McAdams comments that Trump's political narrative "is saturated with a sense of danger and a need for toughness. [...] The world is a dangerous place. You have to be ready to fight." McAdams identifies that many questions have been raised about Trump's "use of inflammatory language, his level of comfort with political violence." He observes: "At campaign rallies, Trump has encouraged his supporters to rough up protesters. 'Get 'em out of 
here,' he yells. 'I'd like to punch him in the face.' From unsympathetic journalists to political rivals, Trump calls his opponents 'disgusting' and writes them off as 'losers."' This rhetoric reinforces Trump's conception of his political narrative as one shaped by his pre-emptive strikes against a series of potential threats to his image or position.

Be tough, or suffer the consequences in this lost, dingy world is how hardboiled protagonists of noir see their options. Ken Hillis contends that these characters' performances are less about the existential ideal of being able to decide and assert their own subjectivity in a tough world than "commodity-identities" (brands, if you will) that come at the price of their own emptiness and loss of connection (Hillis 31). Within this view, noir toughness reflects the individual's relative impotence, the view of oneself as up against a crushing, overwhelming opponent - of wealth, of industry, of governmental power. While this perception of hardboiledness may help to explain Trump's appeal to the disenfranchised (largely male, largely whiteii) voters who support him, it does little to coincide with the reality of his own class position and constant expressions of superiority and social dominance. The performance of toughness in noir-what Hillis refers to as a "masking of the self" and a strategy frequently depicted as "making do"-is a surface posture, a defensive "mask-as-identity" that is intended to buffer oneself against the difficulties of achieving self-importance due to unequal access to economic opportunities and failed expectations $(8,31)$.

Within this classical noir paradigm, then, hardboiled toughness is a persona that masks perceptions of powerlessness and loss. As Hillis writes, "[d]onning a tough persona, or performing it obsessively so that it becomes the self, compensates for having internalized the belief that one has failed [to be fully in the know]" (30). Similarly, noir narratives often focus on the intersections between common citizens and powerful figures intent upon perpetuating or extending their social domination, "quite often tracking 'little people' who tried to tap into such a circuit but ended up being caught in its corruption" (Wilson 488). Yet, the noir appeal of hardboiled toughness stemming from failure within the capitalist endeavour, or finding oneself struggling and marginalised within it, seems particularly incongruous with Trump's narrative, by which business/capitalist success and net worth is equated with the moral superiority of "winners" and justification for dominating others. Within Trump's paradigm, aggression provides further justification for ensuring social dominance, rather than its refutation.

Much of the way Trump's discourse subverts the image of hardboiled "defender of the little guy" that he ostensibly emulates in crafting his political persona has to do with issues of agency. The noir hero's alienation and anger stem largely from the limits of individual agency against a corrupt world of consolidated power. The hardboiled protagonist is excluded partly out of rebellion, but partly also out of his exclusion by the power-brokers. The noir protagonist's rootlessness, his physical and emotional lack of connection, are related to an anxiety of place, an awareness not only of injustices but of the personal inability to alter those realities. While these perceptions of frustrated agency and authority to remedy failed expectations may be reflective of many of Trump's supporters, there is little indication of Trump's sympathy or ability to relate. "For the most part," biographer Michael Barbaro quotes Trump as saying, "you can't respect people because most people aren't worthy of respect" ("How Donald Trump Mastered Twitter").

While Trump incorporates the rhetoric of outsider rebel to his political persona, he simultaneously accords himself absolute agency. Defending why "so many millions" tuned in to hear him in the Primary, pre-nomination debates, he boasts, "Why do you think people tuned in? To hear the nasty questions? To watch a bunch of politicians trying to pretend they are outsiders (like I truly am) so they can be more successful? The fact is that I give people what they need and deserve to hear-exactly what they don't get from politicians-and that is The 
Truth" (Crippled America 8). The underlying subtext is not one of rebelliousness against systemic power, but rather the boastful assertion of authoritative knowledge writ large. In examining this relationship between the self and the social in Trump's construction of his individual narrative, McAdams likens Trump's political persona to that of that of Jung's archetypal warrior. McAdams observes [the warrior's] "typical response to a problem is to slay it or otherwise defeat it; his greatest fear is weakness or impotence. The greatest risk for the warrior is that he incites gratuitous violence in others, and brings it upon himself." Similarly, JJ Jonas notes that " $\mathrm{t}] \mathrm{his}$ archetype helps us to set and achieve goals, overcome obstacles, and persist in difficult times, although it also tends to see others as enemies and to think in either/or terms. The warrior is relatively simple in their thought patterns, seeking simply to win whatever confronts them, including the dragons that live inside the mind and their underlying fear of weakness" ("Twelve Archetypes"). Jung, however, posited that there is also a "shadow" archetype, which reflects the unknown or hidden dark side of the personality. This shadow uses Warrior skills of toughness "for personal gain without thought of morality, ethics, or the good of the whole group," and is "active in our lives anytime we feel compelled to compromise our principles in order to compete, win, or get our own way. [...] It is also seen in a tendency to be continually embattled, so that one perceives virtually everything that happens as a slight, a threat or a challenge to be confronted" ("Twelve Archetypes").

This association of Trump's persona with the Warrior archetype, then, reveals both his persona as strategic mask-the effort to "impress and conceal" (through his self-narrative of relentless winner) - and a darker side of subjectivity (the shadow) that his persona cannot fully obscure (Jung, qtd in Marshall and Barbour 4).

\section{NOSTALGIA, LOSS AND THE AMERICAN SUCCESS MYTH}

I want to connect these conceptions of the Warrior and its shadow with the uses of nostalgia and the success myth that also form prominent subtexts mediating Trump's noir-like narrative and persona. Cawelti refers to the demythologising function of nostalgia that is "powerfully evoked" but in a way that simultaneously undercuts its supposedly comforting message, revealing instead an "inadequate or destructive myth" (507). Trump embeds as a key facet of his political persona his capacity to "restore" the American dream, the assurance that he will "make America great again" (Crippled America 8). If nostalgia draws from the "sense that something important that one once possessed has been lost" (Gilmore 121), Trump has built his political persona around the image that he is uniquely capable of restoring this ineffable imaginary, this missing object of "greatness" - whatever that might mean. Richard Gilmore observes that nostalgia pervades film noir because it underlies the genre's characteristic desperation and violence:

Wild risks are taken because of a desperate faith that the game can be won, that the lost thing can be recovered. The 'thing' in the idea of nostos is home, or, more accurately for film noir, some romanticized idea of what would constitute a sense of finally being home. I am using home now for as a word for feeling like you are where you belong. [...] One longs for this precisely because one feels its absence. (121)

Noir's hardboiled protagonists identify with that sense of loss and alienation, the fracturing of the subject between where it is and where it aspires to be.iii In noir, this sense of loss is not confronted directly, but rather projected onto another who can be assigned responsibility or absorb the blame for this absence or failure. Hillis similarly argues "the noir world indicates how modern notions of subjectivity [...] are deployed to reject the explanation of the power of fate (frequently suggested in these films as equal to gender and class position) in favor of 
instrumental notions of personal failings. This displacement leads to the constellation of classand gender-ridden 'blame the victim' strategies on view within noir" (11). In constructing his political persona, Trump actively leverages this combination of nostalgia and racial/gendered/xenophobic anxiety, projecting responsibility for this lost sense of power and subjectivity on a host of "othered" antagonists.

Noir can function as both "trenchant social analysis" and "thinly veiled ethnic and/or class resentment" (Wilson 504). Within this dual mode, intersections with broader cultural and political discourses around gender, race, and citizenship manifest a "potent but often unconscious estrangement from civil society, typically expressed through the white detective's phantasmal border work with threatening racialized or gendered others" (Wilson 487).iv Trump's constant promise to "bring back" things that have been "lost" represents American possibility as defined by external threats and the need to defend against powerlessness in the face of them. He claims, "I'd bring back waterboarding. I'd bring back a hell of a lot worse" (Democracy Now). In externalising the "pervasive sense of loss among many of his supportersthe belief that the changes molding modern America have marginalized them economically, demographically, and culturally," and placing blame elsewhere, Trump's use of nostalgia allows him to "evoke a hazy earlier time when American life worked better for the overwhelmingly white, heavily blue-collar coalition now drawn to him" (Brownstein). In this manipulation and expansion of a sense of powerlessness in the face of circumstance, Trump reinforces the deepening of social and economic anxieties and divisiveness often reflected in noir. As Ronald Brownstein observes:

The growing groups long eclipsed in American life have no idealized past moment they are longing to restore. A young Hispanic lawyer or middle-aged professional woman might not think they are treated equally today, but few are likely to believe people like them enjoyed more opportunities decades ago. The same is true for other racial and religious minorities, gays and transgender people. For all of these groups, the past that Trump evokes is one that kept them subordinate, in the shadows, or worse.

Just as in classical noir the hardboiled hero's tough exterior is a posture against his awareness of his relative lack of social power. His external projection of that anger and frustration onto women and others reflects his own deeply divided subjectivity and self-misrecognition over the limits of agency. That is, the hardboiled protagonist struggles with the conflict between internal desires and what he (or, rarely, she) is outwardly able to achieve. By manipulating this sense of powerlessness and loss in the crafting of his political persona, Trump directly undermines the meaning of the hardboiled narrative he seems to adopt. Robert Reich maintains that "the economic stresses almost a century ago that culminated in the Great Depression were far worse than most of Trump's followers have experienced, but they've suffered something that in some respects is more painful—failed expectations. [...] Add fears and uncertainties about terrorists who may be living among us or may want to sneak through our borders, and this vulnerability and powerlessness is magnified." In turn, Trump has leveraged these lost expectations not out of identification but to define a political persona based around "restoring" social dominance and winning. "By winning," Franklin Foer comments, "Trump means asserting superiority. And since life is a zero-sum game, superiority can only be achieved at someone else's expense."

In "Crime, Guilt, and Subjectivity in Film Noir," Winfried Fluck describes three versions of the noir protagonist that each define issues of guilt and responsibility differently. In the first, the one we would most closely associate with the "self-reliant outlaw hero," the hardboiled protagonist only masquerades as a lawless tough guy but is never at any real risk of moving over to the dark side. Rather, his apparent contempt for the law is actually an expression of his 
strong inner-directedness and striving for autonomy (401). Under this view, the performance of toughness in noir is indeed a "masking of the self" (Hillis 8). Since society is regarded as irredeemably corrupt, the noir hero is left alone to find another source of worth and selfrespect. His dilemma "is how to adapt methods and skills from the semantic field of 'badness' without becoming corrupted by them" (Fluck 387). Within this conception, the hardboiled noir protagonist "never lacks self-knowledge and never loses control over his role-play" (Fluck 401).

Yet in appropriating this narrative of self-preservation and conflating it with selfinterest, Trump both distorts and loses control over it, demonstrating it as a contrivance that begins to fall apart. Absent any connectivity to the real social drivers that underlie the noir persona that he constructs, it becomes virtually an empty or malleable sign, open to be defined by emotion, impulse, and contingency. In turn, rather than affirming the warrior archetype, Trump exposes the shadow-warrior aspects of his persona. By focusing on winning as an end in itself, "without thought of morality, ethics, or the good of the whole group," Trump's warrior narrative fails to tell us much about what he actually believes in or "where he might direct his energy and anger [...] beyond winning at any cost" (McAdams). While Trump has sought to posit all sorts of suspicious externalities and malevolent subterfuges that are subverting his political success, to cultivate a narrative that individual business success will beget success for the country, and to incriminate others as losers and failures, these narratives have progressively spun out under his inability to control his own destructive impulses. Elaborating on the emptiness of Trump's “warrior-ness," McAdams comments: "It is as if Trump has invested so much of himself in developing and refining his socially dominant role that he has nothing left over to create a meaningful story for his life, or for the nation."

\section{GATEKEEPERS AND TRUMP's NOIR PERSONA}

As gatekeepers of public political identities, the media have played a powerful role in the construction and mediation of Trump's persona. It is not only Trump who uses noir imagery provocatively to shape his political image. Media images frequently present Trump through distorted angles, extreme close-ups, dark lighting, and contrasting light and shadow characteristic of noir (see Figure 2). At the same time, by benefiting from the promotion of

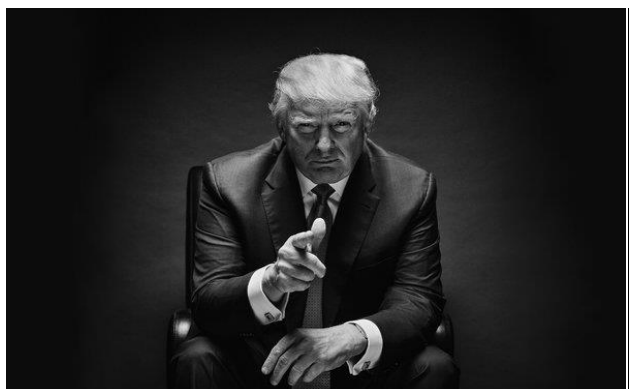

(Source: Damon Winter/New York Times)

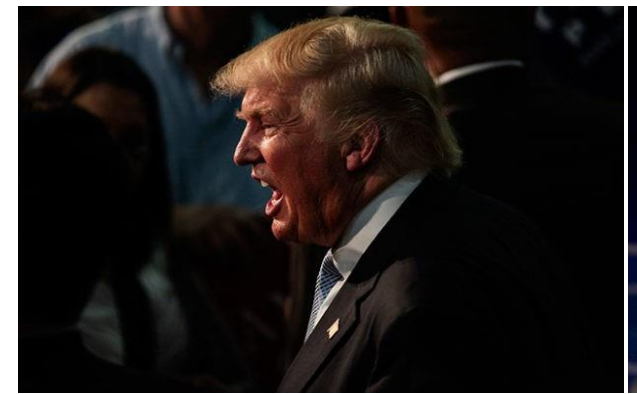

(Source: Nick Cote/New York Times)

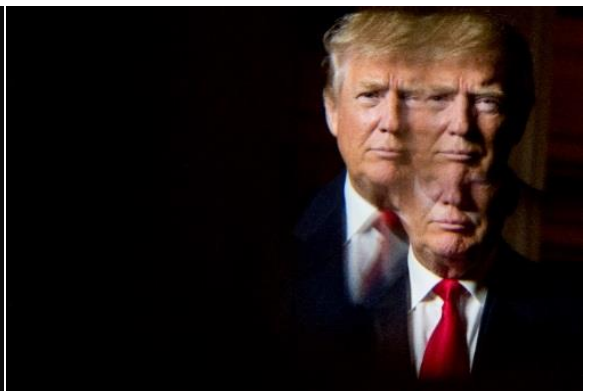

(Source: Andrew Hamik/AP)

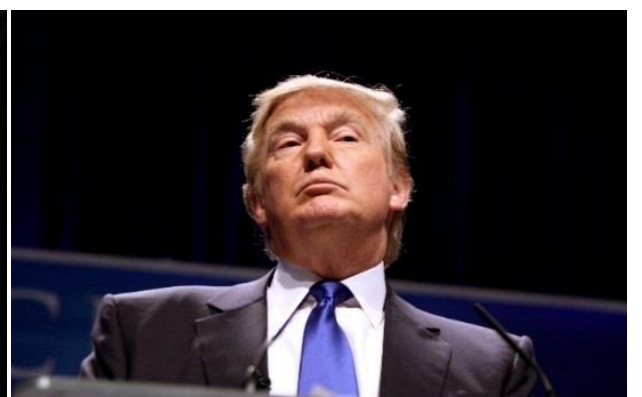

(Source: Gage Skidmore) 
Trump-as-spectacle, the media have also been self-interestedly complicit in facilitating Trump's narrative and hardboiled political persona, and in turn have further substantiated its mutually exploitative and publicly noir character.

Trump has maintained that his relationship with the mainstream media is symbiotic: "The cost of a full-page ad in the New York Times can be more than $\$ 100,000$. But when they write a story about one of my deals, it doesn't cost me a cent, and I get more important publicity. I have a mutually profitable two-way relationship with the media-we each give each other what we need" (Crippled America 11). He's argued that journalists are "like sharks, hoping I'll put some blood in the water. I try to oblige" (Crippled America 149). And he's claimed that even when the press is negative, it still enhances his "brand": I don't mind being attacked. I use the media the way the media uses me-to attract attention. Once I have that attention, it's up to me to use it to my advantage. [...] So sometimes I make outrageous comments and give them what they want - viewers and readers - in order to make a point. I'm a businessman with a brand to sell" (Crippled America 11). By so unabashedly representing his political persona as a negotiated construction, a kind of "deal" ("Deals are my art form" Art of the Deal 3) that he orchestrates with the press, Trump emphasises its discursive nature. In contrast to the hardboiled protagonist who holds true to a core set of values as a mainstay in an unreliable world, Trump's "resignifications of identity" rely on "playing" and "performing" to what sells (Marshall and Barbour 5).

Numerous analyses ${ }^{v}$ have commented both on Trump's unusual media dominance and the way that the mainstream media have cultivated Trump's political rise in the pursuit of their own ratings. Referring to him as "arguably the first bona fide media-created presidential nominee," Harvard political scientist Thomas Patterson found remarkable "that the media seemed to give him front-runner status even though he was not atop the polls and was far down the fundraising list," which was vastly more coverage than his rivals. Neal Gabler reflects that "Trump was indeed gaining ground. But here's the thing: he was gaining ground in some measure, probably a large one, because the media were awarding him disproportionate coverage. It was yet another post-modernist twist: the media jacked up by their own jacking up." Notably, the media benefited the most from Trump's most outrageous or incendiary statements. CBS Chairman Les Moonves said Trump's candidacy "may not be good for America, but it's damn good for CBS." (Politico). Gabler further comments that "[p]romoting Trump, creating Trump, makes the MSM [mainstream media] relevant again. Whatever damage it does to our politics is, apparently, a small price to pay for higher ratings." For both Trump and the media, his persona has been perceived as a product, a marketable commodity, and its performative sensationalism as good business. This symbiosis between Trump's self-interest and the media deepens the noir picture of America.

The noir symbolic of Trump's persona and of his candidacy are further confusingly embedded in American political culture because he invites a chicken and egg problem. The New York Times' Mark Leibovich questions: "Was Trump the logical byproduct of a cancerous system in which American democracy has mutated into a gold rush of cheap celebrity, wealth creation, and narcissistic branding madness? Or has he merely wielded the tools of this transformationhis money, celebrity and dominance of the media-against the forces that engendered this disgust in the first place?" That is, Trump's persona of aggressive disruptiveness can be alternatively read as emblematising both sides of noir. On the one hand, it can be conceived of as a brazen willingness to oppose the old-guard establishment and entrenched political power. On the other, it can be seen as further substantiation of Trump's own media-embeddedness and 
exploitation of his pre-campaign wealth and power. As Jill Lepore suggests, "Trump is the last person to credibly claim to be an outsider. He is a media emperor, tweeting from his Tower."

In promoting his seemingly unscripted and instinctual style (what McAdams has referred to as "the very best weaponry for an entertainment industry"), both Trump and the media play off his strategies of volatility, unpredictability, and immediacy. John Corner categorises three broad cultural and performative dimensions of mediated political persona. The first, political publicity, projects politicians favourably or unfavourably depending upon ideology and party affiliation. We could associate this with political "spin." The second, interactive newsmaking, involves politicians (or their surrogates) participating in news commentary. And the third, what he calls "journalistic revelation" is when stories emerge (often without any political cooperation at all, or through leaked information) which are critical of a politician (395). What is notable is the way that these categorisations try to delineate the borders of privacy (the private self of the politician) from the public and performative persona.

Part of the performative noir aspect of Trump's persona is his brash expression of the seemingly private in the most public of ways. Noir is a mode that claims to look beneath the surface to show us the murkiness underneath. Trump both externalises and embodies this dark confessional. What would typically be repressed (in a conventional candidate and citizen) is exposed and capitalised on, both in an effort to bolster Trump's own brand (and its relationship to political persona), and also to benefit media ratings.

Through the almost constant mediated promotion of both his political and private self (via Twitter and other social media), Trump further muddles the public/private delineation. Trump's use of social media as a more direct and unfiltered method of communication with the public, as compared to conventional media, can in some ways be seen as democratising. However, he more frequently uses it derisively, not as a form of connection but of imposition. "I can let people know they were a fraud," he argues. "I can let people know that they have no talent, and that they didn't know what they were doing. You have a voice" (Barbaro, "How Donald Trump Mastered Twitter"). Commenting on Trump's forceful use of his @realDonald Trump tweets as personal and political weapon, Oren Tsur et al analyse his "proclivity for using Twitter to launch personal attacks on specific individuals" ("Twitter Takeover"). According to The New York Times, over the past 16 months and nearly 4000 tweets, Trump has aimed insults at as many as 282 different targets (Lee and Quealy). On many occasions his social media bursts have gone far beyond his followers to dominate the news for days. Promulgating his hardboiled outsider role, he has tried to both use and get around the constraints of mainstream media, reconfiguring himself as his own gatekeeper within this participatory online culture as forms of "revelation and performativity that allow the social to move into the previously private" (Marshall and Barbour 5).vi

Moreover, Trump's distinctive on-screen rhetoric and body language have provided particularly strong evidence both of his effort to present an aggressive public posture in line with his hardboiled persona and of the way he has frequently distorted and lost control over this public persona. In each of the three Presidential debates, he was easily provoked into personal attacks profoundly unrelated to public governance. His derogatory comments about television personality Rosie O'Donnell, or his under-the-breath, but on-camera critique of Clinton as a "nasty woman" are cases in point. In the second "Town Hall" style debate, he physically shadowed Clinton around the stage in a manner that seemed aimed at projecting dominance to throw her off her game. However, this instead resulted in him appearing predatory, more insistently uncomfortable and out-of-place rather than forceful. His facial 
expressions also fail to contain his private disdain, contrasting with the focused sarcasm of the hardboiled protagonist, whose private life and internal subjectivity remain firmly guarded.

Despite the importance of persona to articulate the relationship between the "individual and the social" (Marshall and Barbour 1), the media have tended to evaluate Trump's persona in ways that neglect this broader dynamic and that thus distort his influence, assigning him too much agency or too little. Cawelti observes how the resurfacing of noir reflects shifts in culture or exposes the limitations of its myths. If Trump's political persona reflects in many ways a resurfacing of noir in its unbridled exposé of self-interested expediency, it also reflects new indeterminacies and uncertainties over how to respond. As Mark Leibovich comments: "What I saw was polite routines and traditions breaking down as the political order reoriented itself around a new center of gravity." Burlesque is one strategy that has transformed noir and encouraged us to reconsider and adapt its contemporary role to comment on and critique social reality (Cawelti). Under this formation, the characteristic toughness and vison of the hardboiled protagonist are "undermined through irony or parody and shown to be insufficient" (506-7). Early in Trump's presidential candidacy, especially, there was a tendency among many pundits to read Trump as nothing more than a joke-a clown or buffoon. Leibovich notes the media's "fear of abetting a circus," and his own prior conception of Trump as a "cartoonish demagogue." In perhaps more benevolent fashion, Maureen Dowd comments, "I enjoy Trump's hyberbolic, un P.C. flights because there are too few operatic characters in this world. I think of him as a Toon. He's just drawn that way."

Alternatively, Trump's economic and political abuses of power and moral decrepitude have been depicted in terms of a destructiveness and evil that eludes any moral complexity"an existence unmolested by the rumbling of a soul" (McAdams). Yet, in envisioning Trump as either a laughable buffoon or an all-powerful villain, to what extent do these representations merely sensationalise Trump or turn him into a caricature that avoids deeper questioning of what is behind the "strategic mask"?

Various analysts have noted the seeming emptiness of the self behind Trump's persona. In his biography of Donald Trump, Michael D'Antonio reports “It was Donald Trump playing Donald Trump. [...] There was something unreal about it." Leibovich states that "Trump might be the single most self-involved yet least introspective person I have ever met in my life, in or out of politics. [...] It's unsettling to encounter a prospective leader whose persona is so conspicuous and well-defined and yet whose core is so obtuse." Reflecting on his political campaign and persona, Trump himself frames it in these terms: "Some people think it will be good for my brand. [...] I think it will be irrelevant for my brand" (Leibovich).

This hollowness suggests one of the central ways Trump discredits his persona as a hardboiled protagonist. Rather than hardening himself externally because of the internal loss of trust in a world gone awry, Trump empties this existential malaise of its meaning, making it all about marketed image and brand identity. Moreover, Persona Studies affirms its relevance not only through what the construction of Trump's persona reveals about the inner Trump (whoever that may be), but also in the interplay with the wider cultural and political discourses of our time. One psychological argument that may underlie support for Trump is voyeuristic pleasure in seeing Trump break the rules and "get away with" things that frustrated individuals might feel guilty for expressing themselves. For those who oppose him, there may also be selfcongratulatory pleasure in his take-down, the moral superiority that affirms someone else's guilt and one's own relative innocence. vii Yet, in noir-like realities, "closure" remains elusive; even if individual crimes can be solved, "the inequities in the status quo commonly remain in place" (Wilson 487). Even if we could solve all the mysteries of Trump, the underlying social and 
political fractures which have substantiated his rise would not miraculously go away. "In noir," as Nicholas Seeley highlights, "the problem is not an individual: the problem is the world."

The mediation of Trump's political persona through the cultural imagery of noir communicates the significance of this identity as both emblematic of a noir-like context and a call for how a noir mindset is needed to examine difficult underlying realities his candidacy has exposed. As metacritical modes, both Persona Studies and noir narratives provide potent vehicles for contesting surface meanings and laying bare hollowed out rhetoric. Persona Studies invites us to investigate and articulate "the play of persona historically and in contemporary culture" (Marshall and Barbour 1) from a point of suspicion with respect to the public self. Similarly, at its best, noir - as a mode of investigation-"changes what we think we know or think we can hear; it rewrites the lines of causation we think we can discern" (Wilson 489). Taken together, both can remind us of abuses of power, but also the importance of culture that questions the imposition of meaning and authority and defiantly keeps those in play.

\section{END NOTES}

i Notably, Trump published a paperback version of this same text eight months later, entitled Great Again: How to Fix Our Crippled America, with a cover markedly less noir and more symbolically nationalistic. What I find especially interesting about this is how, with no change to their textual content, these covers could be so diametrically different within an eight-month span.

ii A December 2016 Washington Post analysis found that Trump's supporters skewed male, white, and low-income. The male-female gap was 19 percentage points ( $47 \%$ men versus $28 \%$ women) (Cited in "Who Are Donald Trump's Supporters, Really?", The Atlantic 1 Mar 2016). Similarly, a Washington Post-ABC News poll suggests that Trump's supporters are not just overwhelmingly white. They are also largely male. In the Post-ABC poll, nearly two out of every three people supporting Trump were men ("What We Mean When We Say Donald Trump's Supporters are 'Struggling”' Washington Post 13 May 2016).

iii The data on white male Trump supporters cited above (endnote 4) may also help explain why Trump's supporters are so nostalgic for bygone times. A recent poll by the Pew Research Center found that three out of every four people supporting Trump said life in America was better "for people like them" 50 years ago. Among all voters, fewer than half agreed (cited in "What We Mean When We Say Donald Trump's Supporters are 'Struggling”' Washington Post 13 May 2016).

iv See also Rabinowitz 2002; Entin 2010; Auerbach 2008; Breu 2006.

v The examples are too numerous to cite. For an interesting overall analysis, see: "The Case Against the Media. By the Media": http://nymag.com/daily/intelligencer/2016/07/caseagainst-media.html.

vi Of interest, too, is Jill Lepore's argument that "as social media ties loosen the old, elitist bonds on politics with their immediacy and increased participation, they reach a point where they outpace our ability to process the information they provide. As a result, they subvert rather than aid in our understanding" (Gabler). In what has often been referred to as "post-truth" culture, individuals are trying to process so much information from so many different sources, that they can't effectively prioritise what's true. Noir emerges in a context of moral and 
epistemological uncertainty that seems to be deepening in our times, and of which Trump is just one prominent example.

vii In an effort to explain why the "dramatizations of self-dissolution" of film noir should be so popular, Fluck suggests that "one reason for the appeal of the 'low' may be sought in the fact that it permits the articulation of impulses that may still be considered 'extreme' but are nonetheless 'tempting.' Fluck notes, "film noir has a highly performative dimension that invites pleasure in imaginary participation without actual emotional involvement" (404-5).

\section{WORKS CITED}

Abrams, Jerold. "Space, Time, and Subjectivity in Neo-Noir." The Philosophy of NeoNoir. Ed. Mark T. Conrad. Lexington: University Press of Kentucky, 2007. 7-20. Print.

Auerbach, Jonathan. "Noir Citizenship: Anthony Mann's 'Border Incident.'" Cinema Journal 47.4 (2008): 102-20. Print.

Barbaro, Michael. "Pithy, Mean and Powerful: How Donald Trump Mastered Twitter for 2016." Web. 5 October 2015.

---. "What Drives Donald Trump? Fear of Losing Status, Tapes Show." The New York Times. Web. 25 October 2016.

Breu, Christopher. Hard-Boiled Masculinities. Minneapolis: University of Minnesota Press, 2006. Print.

Brownstein, Ronald. "Trump's Rhetoric of White Nostalgia." The Atlantic. Web. 2 June 2016.

Cawelti, John. "Chinatown and Generic Transformation in Recent American Films." Film Theory and Criticism (1992): 498-511. Print.

Cober-Lake, Justin. "Hard-Boiled Masculinities." Pop Matters (2016). Web.

Collins, Eliza. "Les Moonves: "Trump's Run is Damn Good for CBS"." Politico. Web. 29 Feburary 2016.

Corner, John. "Mediated Persona and Political Culture: Dimensions of Structure and Process." European Journal of Cultural Studies 3.3 (2000): 386-402. Print .

Davies, William. "The Age of Post-Truth Politics." New York Times. Web. 24 August 2016.

Detrick, Paul. "Donald Trump's Win on Super Tuesday Proves He's Terrifyingly Real." Reason.com. Web. 5 March 2016.

Dowd, Maureen. "Trump the Disrupter." New York Times: Sunday Review. Web. 8 August 2015.

Edsall, Thomas B. "Purity, Disgust and Donald Trump." The New York Times. Web. 6 January 2016.

Ehrenfreund, Max. "What We Mean When We Say Donald Trump's Supporters Are Struggling." The Washington Post. Web. 13 May 2016.

Entin, Joseph. "'Terribly Incomplete Things': No-No Boy and the Ugly Feelings of Noir." MELUS 35.3 (2010): 85-104. Print.

Fluck, Winfried. "Crime, Guilt and Subjectivity in Film Noir." Amerikastudien/American Studies 46.3 (2001): 379-408. Print.

Foer, Franklin. "Donald Trump Hates Women." Web. 24 March 2016.

Gabler, Neal. "How the Media Overthrew Politics." Moyers and Company. Web. 6 July 2016.

Giddens, Anthony. Modernity and Self-Identity: Self and Society in the Late Modern Age. Stanford: Stanford University Press, 1991. Print .

Gilmore, Richard. "The Dark Sublimity of Chinatown." The Philosophy of Neo-Noir. Ed. Mark T. Conrad. Lexington: University Press of Kentucky, 2007. 119-136. Print.

Hillis, Ken. "Film Noir and the American Dream: The Dark Side of Enlightenment." Velvet Light Trap 55 (2005): 1-18. Print.

Jonas, JJ. The Twelve Archetypes. n.d. Web. 
Lee, Jasmine and Kevin Quealy. "The 282 People, Places, and Things Donald Trump Has Insulted on Twitter: A Complete List." The New York Times. Web. 23 October 2016.

Leibovich, Mark. "Donald Trump Is Not Going Anywhere." New York Times. Web. 29 September 2015.

Lepore, Jill. "The Party Crashers: Is the New Populism About the Image or the Medium?" The New Yorker. Web. 22 February 2016.

Marshall, P. David and Kim Barbour. "Making Intellectual Room for Persona Studies: A New Consciousness and a Shifted Perspective." Persona Studies 1.1 (2015): 1-12. Print.

McAdams, Dan. "The Mind of Donald Trump." The Atlantic (2016). Web.

Patterson, Thomas E. Pre-Primary News Coverage of the 2016 Presidential Race: Trumps; Rise, Sanders' Emergence;, Clinton's' Struggle. 2016. Web.

"Post-Truth Politics: Art of the Lie." Web. 10 September 2016.

Rabinowitz, Paula. Black and White and Noir. New York: Columbia University Press, 2002. Print. Reich, Robert. "An American Fascist." Chicago Tribune. Web. 8 March 2016.

Schuler, Jeanne and Patrick Murrary. "'Anything is Possible Here": Capitalism, Neo-Noir, and Chinatown." The Philosophy of Neo-Noir. Ed. Mark T. Conrad. Lexington: University Press of Kentucky, 2007. 167-182. Print.

Seeley, Nicholas. Noir is Protest Literature: That's Why It's Having a Renaissance. Web. 27 April 2016.

Siegel, Lee. "The Selling of Donald J. Trump." The New York Times. Web. 9 September 2016.

Thompson, Derek. "Who are Donald Trump's Supporters, Really?" The Atlantic. Web. 1 March 2016.

"Trump Leads GOP Charge Embracing Torture: I'd Bring Back a Lot Worse than Waterboarding." Democracy Now. Web. 8 February 2016.

Trump, Donald. Crippled America: How to Make America Great Again. New York: Simon and Schuster, 2015. Print.

Trump, Donald with Tony Schwartz. Trump: The Art of the Deal. New York: Random House, 1987. Print.

Tsur, Oren et al. "The Data Behind Trump's Twitter Takeover." Politico. Web. 29 April 2016.

Wilson, Christopher. "When Noir Meets Nonfiction." Twentieth-Century Literature 61.4 (2015): 484-510. Print. 